\title{
Cytotoxicity in L929 fibroblasts and inhibition of herpes simplex virus type 1 Kupka by estuarine cyanobacteria extracts
}

\author{
Viviana R. Lopes ${ }^{\mathrm{a}, \mathrm{b}}$, Michaela Schmidtkec, M. Helena Fernandes ${ }^{\mathrm{d}}$, Rosário Martins ${ }^{\mathrm{a}}$, e, f, Vitor \\ Vasconcelos $^{\mathrm{a}, \mathrm{b}, \text {, }}$
}

${ }^{a}$ CIIMAR/CIMAR, Centro Interdisciplinar de Investigação Marinha e Ambiental, University of Porto, Rua dos Bragas 289, 4050-123 Porto, Portugal

${ }^{\mathrm{b}}$ Department of Biology, Faculty of Sciences, University of Porto, Rua Campo Alegre s/n, 4169007 Porto, Portugal

${ }^{c}$ Department of Virology and Antiviral Therapy, Jena University Hospital, Hans-Knoell-Street 2, D-07745 Jena, Germany

d Laboratório de Farmacologia e Biocompatibilidade Celular, Faculdade de Medicina Dentária da Universidade do Porto, Rua Dr. Manuel Pereira da Silva, 4200-393 Porto, Portugal

e Escola Superior de Tecnologia da Saúde do Porto, Instituto Politécnico do Porto, Rua Valente Perfeito 322, 4400-330 Vila Nova de Gaia, Portugal

f IBMC-Institute for Molecular and Cell Biology, University of Porto, R.Campo Alegre 823, 4150-180 Porto, Portugal

\begin{abstract}
The cyanobacteria are known to be a rich source of metabolites with a variety of biological activities in different biological systems. In the present work, the bioactivity of aqueous and organic (methanolic and hexane) crude extracts of cyanobacteria isolated from estuarine ecosystems was studied using different bioassays. The assessment of DNA damage on the SOS gene repair region of mutant PQ37 strain of Escherichia coli was performed. Antiviral activity was evaluated against influenza virus, HRV-2, CVB3 and HSV-1 viruses using crystal violet dye uptake on HeLa, MDCK and GMK cell lines. Cytotoxicity evaluation was performed with L929 fibroblasts by MTT assay. Of a total of 18 cyanobacterial isolates studied, only the crude methanolic extract of LEGE 06078 proved to be genotoxic (IF > 1.5) in a dosedependent manner and other four were putative candidates to induce DNA damage. Furthermore, the crude aqueous extract of LEGE 07085 showed anti- herpes type 1 activity (IC50 = 174.10 $\mu \mathrm{g}$ dry extract $\mathrm{mL}^{-1}$ ) while not presenting any cytotoxic activity against GMK cell lines. Of the 54 cyanobacterial extracts tested, only the crude methanolic and hexane ones showed impair on metabolic activity of L929 fibroblasts after long exposure (48-72 h). The inhibition of HSV-1 and the strong cytotoxicity against L929 cells observed
\end{abstract}


emphasizes the importance of evaluating the impact of those estuarine cyanobacteria on aquatic ecosystem and on human health. The data also point out their potential application in HSV-1 treatment and pharmacological interest.

\section{Keywords}

Anti-HSV-1 activity; DNA damage; Estuarine cyanobacteria; Cytotoxicity

\section{Introduction}

Cyanobacteria are prokaryotic oxygenic photoautotroph organisms found in all kind of habitats. They are known worldwide for their ability to produce several types of toxins such as neurotoxins and hepatotoxins (Carmichael, 1994). However, on the last decades cyanobacteria have been also identified as a new and prolific source of bioactive compounds (Abed et al., 2009). The bioactive compounds produced include polyketides, amides, alkaloids, fatty acids, indoles and lipopeptides (Burja et al., 2001 and Patterson et al., 1994). Diverse biological activities have been surveyed and reported, ranging from antiviral, antialgal, antibacterial, antifungal to antitumour activity (Abed et al., 2009 and Bubik et al., 2008).

Previous studies have shown that the cyanotoxins and cyanobacterial extracts can be genotoxic and mutagenic, either with or without metabolic activation, but little information is available (Ding et al., 1999, Mankiewicz et al., 2002, Shen et al., 2002 and Zhan et al., 2004). Moreover, antiviral as well as cytotoxic activity of cyanobacterial extracts has been previously reported. Cyanobacteria belonging to the genera Calothrix, Microcystis, Nodularia, Nostoc, Spirulina, Oscillatoria and Scytonema have been described as producers of compounds with broad-spectrum antiviral properties. The inhibitory concentration $\left(\mathrm{IC}_{50}\right)$ of antiviral activity can range between 0.37 and $300.0 \mu \mathrm{g}$ extract/ml. Spirulan-like substances, polysaccharides, carbohydrates and peptidic compounds have been reported as antiviral compounds against herpesviruses, paramyxoviruses, influenza viruses and human immunodeficiency virus type 1 . Cyanobacteria have been also reported to cause cytotoxicity by induced apoptosis in mammalian cell lines as the human leukemia cell line, and fish cell lines (Hernandez-Corona et al., 2002, Kanekiyo et al., 2007, Mundt et al., 1997, Nowotny et al., 1997, Patterson et al., 1993, Rechter et al., 2006, Surakka et al., 2005, Teneva et al., 2003 and Zainuddin et al., 2002).

- The cyanobacteria ability to produce toxins as well as bioactive secondary metabolites makes these organisms potentially hazardous to aquatic ecosystem and to human health (Carmichael, 2001 and Martins et al., 2008). While toxicity of fresh and marine waters cyanobacterial metabolites has been well documented in vitro and in vivo, few surveys about the bioactivity of estuarine cyanobacteria have been published. Ecotoxicological effects of cyanobacteria of freshwaters and marine biotopes on animals, plants and humans have been reported. Toxigenicity has been mainly linked to the genera Anabaena, Anabaenopsis, Hapalosiphon, Lyngbya, Microcystis, Nostoc, Synechoccocus and Planktothrix. Neurotoxic and hepatotoxic effects as well 
antialgal, immunosuppressive, antimycotic, antibacterial, antitumour and antiviral activity have been described ( Gademann and Portmann, 2008, Hirata et al., 2003, Jaiswal et al., 2008, Martins et al., 2007, Martins et al., 2008, Mundt et al., 2001 and Wiegand and Pflugmacher, 2005). On the other hand, recent studies have already demonstrated that cyanobacteria isolated from estuaries induce toxic effects on marine invertebrates ( Lopes et al., 2010).

- Considering the potential bioactivity of cyanobacteria from estuarine habitats, an assessment of genotoxicity, cytotoxic and antiviral activity of cyanobacteria was done. A battery of four in vitro assays was applied to assess specific potential biological activity. The DNA damage was evaluated using the SOS-Chromotest based on the induction of SOS-repair system of the strain Escherichia coli PQ 37 ( Quillardet et al., 1982). The screening of antiviral activity was done by the evaluation of cytopathic effect using crystal violet dye uptake against coxsackie virus B3 strain, the influenza virus A strain Hong Kong/68, the herpes simplex virus type 1 strain and rhinovirus ( Schmidtke et al., 2001). Cytotoxicity evaluation was also performed with L929 cell lines by MTT assay ( Berridge and Tan, 1993, Freshney, 2000 and Li and Song, 2007).

- 2. Material and methods

- 2.1. Cyanobacterial cultures

- The sampling was performed during the low tide from both benthos and plankton on estuarine systems of North and Centre of Portugal specifically, Minho, Douro and Vouga $\left(42^{\circ} 15^{\prime}\right.$ to $40^{\circ}$ $15^{\prime}$ north latitude and $8^{\circ} 54^{\prime}$ to $8^{\circ} 38^{\prime}$ west longitude). Eighteen cyanobacterial strains were isolated, belonging to six genera Cyanobium, Leptolyngbya, Microcoleus, Nodularia, Nostoc and Synechocystis (see Table 1). Isolation and culture were performed in Z8 medium ( Kotai, 1972) supplemented with $10-35 \mathrm{mg} \mathrm{NaCl} \mathrm{ml}^{-1}$ (P.A. Sigma-Aldrich®, Germany) and at $25{ }^{\circ} \mathrm{C}$, light intensity of $20.8-27.4 \times 10^{-6} \mathrm{E} \mathrm{m}^{-2} \mathrm{~s}^{-1}$ with a light/dark cycle of $14 / 10 \mathrm{~h}$. All the cultures were unicyanobacterial and non-axenic but no visible bacterial contamination was present in any of the cultures. Cultures of the isolates at the exponential growth phase were collected by centrifugation or filtration and washed with bidistilled water, frozen at $-20{ }^{\circ} \mathrm{C}$ and then freeze-dried. 
Table 1.

\begin{tabular}{|c|c|c|c|}
\hline Lab code & Taxon & Lab code & Taxon \\
\hline LEGE 06068 & Cyanobium sp. & LEGE 07075 & Leptolyngbyasp. \\
\hline LEGE 06069 & Leptolyngbyasp. & LEGE 07076 & Microcoleus sp. \\
\hline LEGE 06070 & Leptolyngbyasp. & LEGE 06077 & Nostocsp. \\
\hline LEGE 06071 & Nodulariasp. & LEGE 07080 & Leptolyngbyasp. \\
\hline LEGE 06072 & Phormidium sp. & LEGE 07083 & Synechocystis sp. \\
\hline LEGE 06078 & Phormidium sp. & LEGE 07084 & Leptolyngbyasp. \\
\hline LEGE 06079 & Synechocystis sp. & LEGE 07085 & Leptolyngbyasp. \\
\hline LEGE 07073 & Symechocystis sp. & LEGE 07091 & Leptolyngbya sp. \\
\hline LEGE 07074 & Leptolyngbyasp. & LEGE 07092 & Microcoleus sp. \\
\hline
\end{tabular}

\subsection{Cyanobacterial extracts}

The freeze-dried cells were extracted with $70 \%$ methanol ( $1 \mathrm{ml}$ per $25 \mathrm{mg} \mathrm{dw}$ ) with an ultrasonic probe Vibra cell50 (Sonics \& Materials Inc., Danbury, USA) at $4{ }^{\circ} \mathrm{C}$ during $3 \times 20 \mathrm{~s}$, centrifuged at $9300 \mathrm{~g}$ during $10 \mathrm{~min}$ and evaporated. The obtained residue was resuspended in sterile $0.85 \%$ saline solution with $10 \%$ DMSO (AldraSorb ${ }^{\text {TM }}$ 99.8\% Sigma-Aldrich®, Germany) and used for the genotoxic trial. Regarding the cytotoxic and cytophatic effect assays, a similar procedure was used with slight modifications. Three solvents with increasing polarity were applied, $n$-hexane (P.A. Merck, Germany), methanol (P.A. Merck, Germany) and bidistilled water. The obtained residues were resuspended in the same solvent used for the extraction, except for the hexane which was replaced by 1\% DMSO (AldraSorb ${ }^{\mathrm{TM}}$ 99.8\% Sigma-Aldrich®, Germany).

\subsection{DNA damage assay}

The genotoxic activity was assessed by the SOS Chromotest kit version 6.3 (EBIP, Canada) based on a bacterial colorimetric assay developed by Quillardet and Hofnung (1993) and Quillardet et al. (1982). In brief, it was used a strain of Escherichia coli genetically modified in which the SOS gene promoter has been linked to the Lac $\mathrm{Z}$ gene. DNA damage was evaluated by measuring the absorbance of betagalactosidase (ß-gal) at $615 \mathrm{~nm}$ using a PowerWave ${ }^{\mathrm{TM}}$ Microplate Spectrophotometer (BioTek, USA). Since the analysis and synthesis of the $\beta$-gal enzyme it is dependent upon the viability of bacteria, ATP activity was also tested using alkaline phosphatase (PAL) measuring its absorbance at $405 \mathrm{~nm}$. A standard genotoxic solution was used containing $10 \mu \mathrm{g} \mathrm{mL}^{-1}$ of 4NQO in 10\% DMSO saline. Six twofold dilutions from 0.78 to $25.00 \mathrm{mg} \mathrm{mL}^{-1}$ of the cyanobacterial extracts in $10 \% \mathrm{DMSO}$ saline solution were analyzed in triplicate. The data obtained were expressed as induction factor (IF) defined as (B-gal $\left./ \mathrm{PAL}_{\mathrm{c}}\right) /\left(\mathrm{B}-\mathrm{hal}_{0} / \mathrm{PAL}_{0}\right)$, where 0 represents the negative control (sterile ultrapure water) and $c$ concentration of the sample. 


\subsection{Cytotoxicity assays}

L929 cell lines (ATCC CCL-1 ${ }^{\text {TM}}$ ) were cultured in $\alpha$-MEM (Gibco, Invitrogen No. 11900-073) supplemented with $10 \%$ (v/v) fetal bovine serum (Gibco Invitrogen No. 10106-169), 1\% penicillin and streptomycin solution (Gibco Invitrogen No. 15140-122) and $2.5 \mu \mathrm{g} \mathrm{mL}^{-1}$ of fungizone (Gibco Invitrogen No. 15290-026). Cells were seeded at $3 \times 10^{3}$ cells per well (96-well culture plates) and exposed to the extracts for 24, 48 and 72 h. Cytotoxicity of the extracts was evaluated by the 3-(4, 5-dimethylthiazole-2yl)-2, 5-diphenyltetrazolium bromide (MTT) assay.

Cultures were maintained at $37{ }^{\circ} \mathrm{C}$ in a humidified incubator with $5 \% \mathrm{CO}_{2}$ atmosphere for the incubation times mentioned above, without any medium change. The MTT assay was carried out according to Berridge and Tan (1993). Cultures were exposed to the extracts for 24, 48 and $72 \mathrm{~h}$. At the end of each testing time, the culture supernatants were removed and MTT solution $\left(0.5 \mathrm{mg} \mathrm{mL}^{-1}\right)$ was added to each well and the plates were incubated for $4 \mathrm{~h}$ at $37^{\circ} \mathrm{C}$. The MTT solution was removed and DMSO was added to dissolve formazan crystals. The absorbance at $550 \mathrm{~nm}$ was read on a PowerWave ${ }^{\mathrm{TM}}$ Microplate Spectrophotometer (BioTek, USA). The percentage of viability was calculated as (AT/AC)*100, where $A T$ and $A C$ are the optical densities of treated and control cells, respectively.

\subsection{Antiviral activity}

HeLa Ohio (human cervix carcinoma; ATCC CCL-2 ${ }^{\mathrm{TM}}$ ), GMK (green monkey kidney cells; Schaper and Brümmer, Salzgitter, Germany), and Madin-Darby canine kidney (MDCK) cells (Friedrich-Loeffler Institute, Riems, Germany) were used in the antiviral trials. The HeLa Ohio cells were grown in MEM/E medium (SIGMA No. M-0643), and the GMK and MDCK cells in Dulbecco's modified MEM/E (SIGMA No. D-7777) supplemented with 10\% NCS (HeLa Ohio; Greiner No. 758010, Germany) or 10\% FBS (GMK and MDCK; Greiner No. 758075, Germany), $100 \mathrm{U} / \mathrm{ml}$ penicillin as well as streptomycin (CCpro No. Z-13-M, Germany). The test medium used for the anti-coxsackie virus B3 and anti-herpes simplex virus type 1 tests contained only $2 \%$ of the appropriate serum. The medium applied in the anti-influenza virus-A assays was formulated with $3 \mu \mathrm{g} \mathrm{ml}^{-1}$ trypsin and did not contain serum. All cells were proved to be free of mycoplasma contamination before using. Cultures were maintained at $37{ }^{\circ} \mathrm{C}$ in a humidified incubator with $5 \% \mathrm{CO}_{2}$ atmosphere.

\subsubsection{Viruses}

Virus stocks of the coxsackie-virus B3 strain Nancy (CVB3; Institute of Poliomyelitis and Virus Encephalitides, Moscow, Russia), the influenza virus A/Hong Kong/68 (influenza virus; Schaper and Brümmer, Salzgitter, Germany), the herpes simplex virus type 1 strain Kupka (HSV-1; own strain collection) and rhinovirus type 2 (HRV-2; Institute of Virology, Vienna, Austria) were prepared in HeLa Ohio (CVB3 and HRV-2), MDCK (Influenza virus), and GMK cells (HSV-1). The titre of virus stocks was previously determined by plaque assay on the respective cell monolayer. 


\subsubsection{Cytopathic effect (CPE) inhibitory assay}

The in vitro assay of anti-viral activity was performed applying the protocol of Schmidtke et al. (2001) and Makarov et al. (2005). Briefly, the CPE assay is based on the lysis of HeLa Ohio, MDCK, and GMK cells by CVB3 and HRV-2, influenza virus, and HSV-1 K1, respectively. The antiviral evaluation was carried out in 1-day-old semi confluent (HRV-2) or 2-day-old confluent (CVB3, influenza virus, and HSV-1) monolayers of the mentioned cell lines growing in 96-well flat-bottomed microtiter plates (Falcon 3075). After removal of the culture medium, $50 \mu \mathrm{l}$ of extract solution or medium (cell and control virus) and a constant amount of virus in a volume of $50 \mu \mathrm{l}(0.1$ multiplicity of infection for CVB3 and influenza virus, 0.01 multiplicity of infection for HRV-2) or medium (cell control) were added to the cells. Six wells of non-infected and six wells of infected cells without the test extract were used as cell and virus control, respectively, on each plate. To calibrate the assay, the 50\% and $100 \%$ plaque inhibitory concentrations of reference compounds (each three wells; guanidine hydrochloride for CVB3, pleconaril for HRV-2, amantadine for influenza virus, and foscarnet for HSV-1) were included as positive control in each microtiter plate. Plates were incubated for $24 \mathrm{~h}$ (CVB3 and influenza virus), $48 \mathrm{~h} \mathrm{HSV-1,} \mathrm{or} 72 \mathrm{~h}$ (HRV2) at $37{ }^{\circ} \mathrm{C}$ in a humidified atmosphere with $5 \% \mathrm{CO}_{2}$. At this time a complete cytopathic effect was observed microscopically in virus control wells. The cells were fixed and stained with crystal violet formalin solution. After dye extraction, the optical density of individual wells was quantified at 550/630 nm with a microplate reader. The percentage of antiviral activities of the tests extracts were calculated by ((mean OD of six cell controls-mean OD of six virus controls)/(mean OD of test extract-mean OD of six virus controls) $) \times 100$. The $50 \%$ CPE inhibitory dose $\left(\mathrm{IC}_{50}\right)$ was calculated.

\subsubsection{Cytotoxicity}

The cytotoxicity measurement by the crystal violet dye assay was made simultaneously with the antiviral activity evaluation to guarantee that the potential virus-specific compound or mixture should have low or no effects on cellular metabolism and thus showing none toxicity against the host organism. The $50 \%$ cytotoxic concentration $\left(\mathrm{CC}_{50}\right)$ of the cyanobacterial extracts was determined on 2-day-old confluent HeLa Ohio, MDCK and GMK cell monolayers grown in the internal 60 wells of 96-well tissue culture plates (Falcon 3075) as described by Schmidtke et al. (2001). Briefly, cell monolayers were incubated with eight twofold serial dilutions of compounds for $72 \mathrm{~h}\left(37^{\circ} \mathrm{C}, 5 \% \mathrm{CO}_{2}\right)$. Then, the cells were fixed and stained with a crystal violet formalin solution. After dye extraction, the optical density of individual wells was quantified at 550/630 nm with a microplate reader. Cell viability of individual compound-treated wells was evaluated as the percentage of the mean value of optical density resulting from six mock-treated cell controls which was set $100 \%$. The $\mathrm{CC}_{50}$ was defined as the compound concentration reducing the viability of untreated cell cultures by $50 \%$. It was calculated from the logarithmic regression curves.

\subsection{Chemical analysis - MALDI TOF-MS}


Lyophilised samples of the cyanobacterial cultures, which showed bioactivity, were screened for common cyanotoxins and other peptides by MALDI-TOF MS. The procedure and conditions can be seen in Lopes et al. (2010).

\subsection{Statistical analyses}

Data were expressed as means \pm standard deviation (SD). Significant differences were determined by oneway analysis of variance (ANOVA) at $p<0.05$. The goodness of fit of the data to normal distribution was tested applying the Kolmogorov-Smirnov statistic. The statistical analysis was performed with SPSS software (version 17.0, USA). When the normality and homoscedasticity assumptions were not met, a nonparametric Kolmogorov-Smirnov test for two- independent samples was applied. A significant level of $p<0.05$ was accepted. The $\mathrm{CC}_{50}$, defined as the concentration that caused $50 \%$ maximum cytotoxic effect, was calculated by regression analysis of the dose-response curves for MTT and crystal violet assay.

\section{Results}

The genotoxic effects of the 18 extracts analyzed were evaluated using crude methanolic $70 \%$ (v/v) extracts, without metabolic activation and were expressed through its induction factors (IF). As shown in Table 2, LEGE 06078 showed genotoxic effects, presenting IF values higher than 1.5 and increasing significantly $(p<0.05)$ in a dose-dependent manner. The LEGE 06078 extract belongs to the Phormidium genus. Furthermore, $22 \%$ of the cyanobacterial extracts were potentially genotoxic since at least one of the two parameters evaluated, IF higher than 1.5 and response in a dose-dependent manner, were not verified. Some isolates showed an IF higher than 1.5 from a concentration of $6.25 \mathrm{mg} \mathrm{mL}^{-1}$ but not enough to consider genotoxic. It could be an artifact resulting of a high dose. These candidates belong mainly to Oscillatoriales, the exception being LEGE 06077, which belongs to Nostocales. The remaining isolates have no genotoxicity since the IF values were above 1.0 (not shown), independently of the concentration value. 
Table 2.

SOS induction by crude (70\% v/v) methanolic extracts of $\mathrm{CB}$ on $E$ col/ strain without metabolic activation (S9). The strains not shown in the table had no significant effects. Mean values and standard deviation $(\dot{\mathrm{X}} ; \mathrm{SD})$. Values typeset in bold indicate a positive genotoxicity response and in italics represent a potential genotoxicity.

\begin{tabular}{|c|c|c|c|c|c|c|}
\hline Isolates code & [extract] $\left(\mathrm{mg} \mathrm{mL}^{-1}\right)$ & $P A^{\circ} \mathrm{C}$ & X; SD) & $\beta$-GAL & $\dot{\mathrm{X}} ; \mathrm{SD})$ & $\mathrm{IF}^{\mathrm{b}}$ \\
\hline Oscillatoriales & & & & & & \\
\hline LEGE 06070 & 25.00 & 0.166 & 0.055 & 0.031 & 0.016 & 1.4 \\
\hline & 12.50 & 0.162 & 0.065 & 0.032 & 0.021 & 1.5 \\
\hline & 6.25 & 0.213 & 0.024 & 0.070 & 0.044 & 25 \\
\hline & 3.13 & 0.199 & 0.027 & 0.039 & 0.012 & 1.4 \\
\hline & 1.56 & 0.190 & 0.030 & 0.037 & 0.010 & 1.4 \\
\hline & 0.78 & 0.170 & 0.009 & 0.023 & 0.003 & 1.0 \\
\hline & 0.00 & 0.152 & 0.016 & 0.020 & 0.003 & 1.0 \\
\hline LEGE 06072 & 25.00 & 0.211 & 0.008 & 0.052 & 0.003 & 1.8 \\
\hline & 12.50 & 0.208 & 0.004 & 0.049 & 0.001 & 1.7 \\
\hline & 6.25 & 0.207 & 0.002 & 0.051 & 0.004 & 1.8 \\
\hline & 3.13 & 0.200 & 0.003 & 0.045 & 0.003 & 1.6 \\
\hline & 1.56 & 0.211 & 0.010 & 0.044 & 0.000 & 1.5 \\
\hline & 0.78 & 0.162 & 0.002 & 0.026 & 0.001 & 1.1 \\
\hline & 0.00 & 0.136 & 0.017 & 0.019 & 0.002 & 1.0 \\
\hline LEGE 06078 & 25.00 & 0.210 & 0.009 & 0.056 & 0.004 & 2.2 \\
\hline & 12.50 & 0.210 & 0.007 & 0.053 & 0.002 & 2.1 \\
\hline & 6.25 & 0.212 & 0.003 & 0.055 & 0.002 & 2.2 \\
\hline & 3.13 & 0.207 & 0.004 & 0.045 & 0.003 & $1.9^{\circ}$ \\
\hline & 1.56 & 0.209 & 0.004 & 0.045 & 0.004 & $1.8^{\circ}$ \\
\hline & 0.78 & 0.156 & 0.000 & 0.024 & 0.004 & $1.3^{*}$ \\
\hline & 0.00 & 0.133 & 0.009 & 0.016 & 0.001 & 1.0 \\
\hline
\end{tabular}




\begin{tabular}{|c|c|c|c|c|c|c|c|}
\hline \multirow[t]{7}{*}{ LEGE 07074} & 25.00 & 0.567 & 0.017 & 0.232 & 0.026 & 2.2 & \\
\hline & 12.50 & 0.759 & 0.028 & 0.220 & 0.022 & 1.6 & \\
\hline & 6.25 & 0.834 & 0.021 & 0.216 & 0.023 & 1.4 & \\
\hline & 3.13 & 0.958 & 0.029 & 0.195 & 0.034 & 1.1 & \\
\hline & 1.56 & 0.991 & 0.040 & 0.194 & 0.028 & 1.1 & \\
\hline & 0.78 & 1.080 & 0.005 & 0.149 & 0.039 & 0.8 & \\
\hline & 0.00 & 0.988 & 0.008 & 0.172 & 0.047 & 1.0 & \\
\hline \multicolumn{7}{|l|}{ Nostocales } & \\
\hline \multirow[t]{7}{*}{ LEGE 06077} & 25.00 & 0.643 & 0.034 & 0.235 & 0.017 & 1.9 & \\
\hline & 1250 & 0.823 & 0.103 & 0.245 & 0.028 & 1.6 & \\
\hline & 6.25 & 0.894 & 0.138 & 0.229 & 0.021 & 1.4 & \\
\hline & 3.13 & 0.958 & 0.057 & 0.216 & 0.029 & 1.2 & \\
\hline & 1.56 & 1.153 & 0.205 & 0.208 & 0.040 & 1.0 & \\
\hline & 0.78 & 1.155 & 0.045 & 0.186 & 0.005 & 0.9 & \\
\hline & 0.00 & 0.951 & 0.074 & 0.180 & 0.008 & 1.0 & \\
\hline
\end{tabular}

Cytotoxic effects of cyanobacterial crude extracts were analyzed in L929 mouse fibroblasts by MTT assay performed in cultures exposed for 24, 48 and $72 \mathrm{~h}$. Generally, the extracts were found to be toxic against L929 cell lines. Although no signals of cytotoxicity at 24 h-exposure time were observed for L929 cells, marked cytotoxicity was observed with crude hexane and methanolic extracts for higher exposure times (48 and $72 \mathrm{~h})$.

The analysis of the 54 cyanobacterial extracts revealed 23 extracts with marked cytotoxicity activity at $72 \mathrm{~h}$. The observed cytotoxicity of the extracts against L929 cell line, at $72 \mathrm{~h}$ incubation, expressed as cell viability percentage, is shown in Table 3. The aqueous extracts did not induce any cytotoxic effects on L929 cell line contrarily to the methanolic and $n$-hexane extracts. The methanolic extracts caused $15-85 \%$ loss of cell viability of L929 cells. From a total of 18 methanolic extracts, 12 caused moderate to potent cytotoxic effects, causing $15-50 \%$ inhibition of the cell viability of L929 cell line at $200.0 \mu \mathrm{g} \mathrm{DW} \mathrm{mL} \mathrm{mL}^{-1}$. The occurrence of highest cytotoxicity (15-30\%) was observed for the LEGE06077, 07073 and 07083 methanolic extracts which belong to the Nostocales and Chroococcales order, respectively. The $n$-hexane extracts did induce moderate cytotoxicity ranging from $30 \%$ to $70 \%$ of cell viability at the highest concentration of $200.0 \mu \mathrm{g} \mathrm{DW} \mathrm{mL} \mathrm{mL}^{-1}$. From the $18 n$-hexane extracts, 11 caused $50 \%$ of growth inhibition of L929 cell line at $200.0 \mu \mathrm{g} \mathrm{DW} \mathrm{mL} \mathrm{m}^{-1}$. These extracts fit mainly in the Oscillatoriales group similarly to

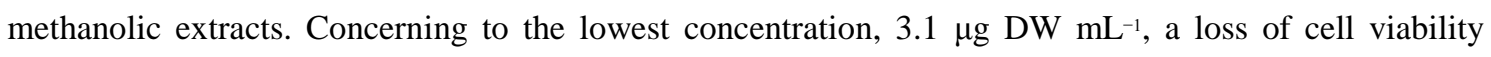
between $0 \%$ and $15 \%$ was observed for the aqueous and $n$-hexane extracts. Besides, it was also observed a 
slight stimulation of cell growth exposed to the aqueous extracts. At $3.1 \mu \mathrm{g} \mathrm{DW} \mathrm{mL} \mathrm{m}^{-1}$ the methanolic extracts were the ones that induced the highest loss cell viability ranging from $8 \%$ to $50 \%$. The one-way analysis (ANOVA) and Kruskal-Wallis statistical analysis revealed that $n$-hexane and methanol extracts are significantly different comparing with the control to $p$-value $<0.05$.

\section{Table 3.}

Cell viability of L929 cell line exposed to the maximum and minimum concentration of cyanobacterial extracts (CB) for $72 \mathrm{~h}$. Results are expressed as percentage of control. $\mathrm{H}$ - n-hexane extracts; $\mathrm{M}$ - methanolic extracts; $\mathrm{W}$ - aqueous extracts. Bold values indicate results with cell viability above $50 \%$

Cell viability (\%) of L929 exposed to CB extracts

\begin{tabular}{|c|c|c|c|c|c|c|}
\hline \multirow{2}{*}{$\begin{array}{l}\text { Isolate } \\
\text { code }\end{array}$} & \multicolumn{2}{|l|}{$[\mathrm{H}]$} & \multicolumn{2}{|l|}{ [M] } & \multicolumn{2}{|l|}{ [W] } \\
\hline & $200 \mu \mathrm{g} \mathrm{DW} \mathrm{mL}^{-1}$ & $3.1 \mu \mathrm{g} \mathrm{DW} \mathrm{mL} \mathrm{m}^{-1}$ & $200.0 \mu \mathrm{gWW} \mathrm{mL}^{-1}$ & $3.1 \mu \mathrm{g} \mathrm{DW} \mathrm{mL}^{-1}$ & $200.0 \mu \mathrm{g} \mathrm{DW} \mathrm{mL} \mathrm{mL}^{-1}$ & $3.1 \mu \mathrm{g} \mathrm{DW} \mathrm{mL} \mathrm{mL}^{-1}$ \\
\hline \multicolumn{7}{|c|}{ Chroococcales } \\
\hline $\begin{array}{l}\text { LEGE } \\
06068\end{array}$ & 412 & 93.4 & 71.1 & 80.4 & 61.4 & 94.3 \\
\hline $\begin{array}{l}\text { LEGE } \\
07073\end{array}$ & 54.9 & 87.6 & 29.6 & 59.9 & 81.8 & 124.4 \\
\hline $\begin{array}{l}\text { LEGE } \\
07083\end{array}$ & 49.9 & 86.3 & 18.7 & 48.7 & 91.2 & 115.4 \\
\hline $\begin{array}{l}\text { LEGE } \\
06079\end{array}$ & 39.2 & 89.6 & 41.6 & 76.6 & 92.4 & 93.3 \\
\hline
\end{tabular}




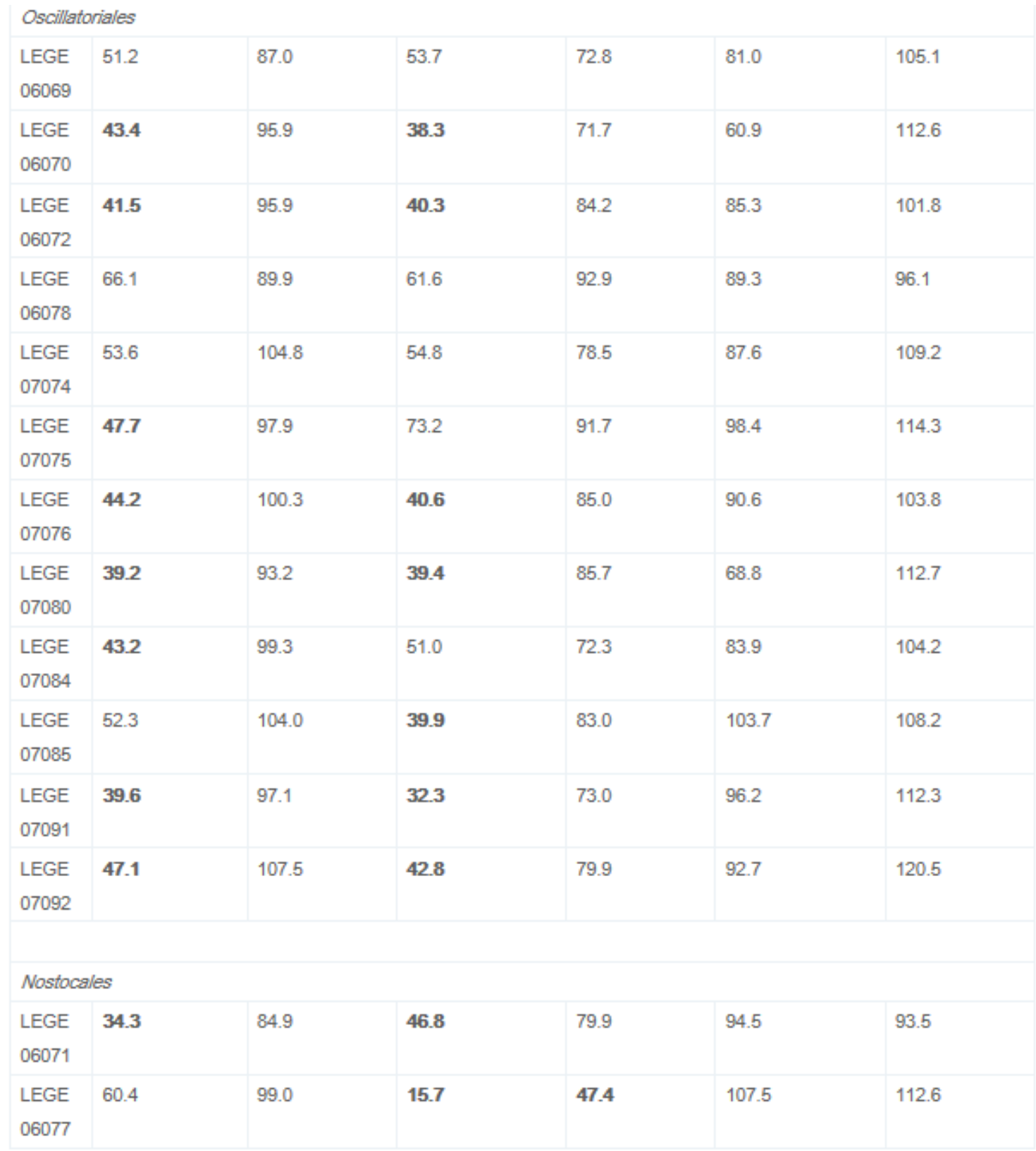

The CC50 values determined to $n$-hexane and methanolic extracts are expressed in Table 4 . The strongest cytotoxicity ( $<45 \mu \mathrm{g} \mathrm{mL}^{-1}$ ) was determined for methanolic extracts of LEGE 07073 and LEGE 07083 from the Chroococcales group and LEGE 06077 belonging to Nostocales group. 
Table 4.

Cytotoxicity of CB hexane and methanolic extract on $\mathrm{L} 929$ cell line exposed $72 \mathrm{~h}$. NCT - not cytotoxic in the tested dose range; H n-hexane extracts; $\mathrm{M}$ - methanolic extracts; Bold values mean strong cytotoxicity.

\begin{tabular}{|c|c|c|c|c|c|}
\hline \multirow[b]{2}{*}{ Isolate code } & \multicolumn{5}{|c|}{$\mathrm{CC}_{50}\left(\mu \mathrm{g} \mathrm{mL}^{-1}\right)$} \\
\hline & $\mathrm{H}$ & \multicolumn{2}{|l|}{ M } & H & $M$ \\
\hline \multicolumn{6}{|c|}{ Chroococcales } \\
\hline LEGE 06068 & 79.28 & NTC & LEGE 07073 & NTC & 40.86 \\
\hline LEGE 06079 & 75.35 & 67.59 & LEGE 07083 & 74.72 & 25.80 \\
\hline \multicolumn{6}{|l|}{ Oscillatoriales } \\
\hline LEGE 06070 & 82.76 & 57.42 & LEGE 07076 & 83.90 & 73.67 \\
\hline LEGE 06072 & 78.64 & 69.74 & LEGE 07080 & 81.88 & 67.99 \\
\hline LEGE 06069 & 189.97 & NTC & LEGE 07084 & 74.35 & NTC \\
\hline LEGE 06078 & NCT & NTC & LEGE 07085 & NTC & 64.35 \\
\hline LEGE 07074 & NTC & NTC & LEGE 07091 & 81.78 & 63.92 \\
\hline LEGE 07075 & 85.10 & NTC & LEGE 07092 & 88.70 & 71.35 \\
\hline \multicolumn{6}{|l|}{ Nostocales } \\
\hline LEGE 06071 & 72.47 & 68.07 & LEGE 06077 & NTC & 29.06 \\
\hline
\end{tabular}

It was also observed that cytotoxicity in L929 cells increases in a dose and time dependent manner as shown to the three extracts with highest $\mathrm{CC}_{50}$ values in Fig. 1. The ANOVA analysis also revealed that values of three mentioned extracts are significantly different $(p$-value $<0.05)$ for the series of concentrations used.

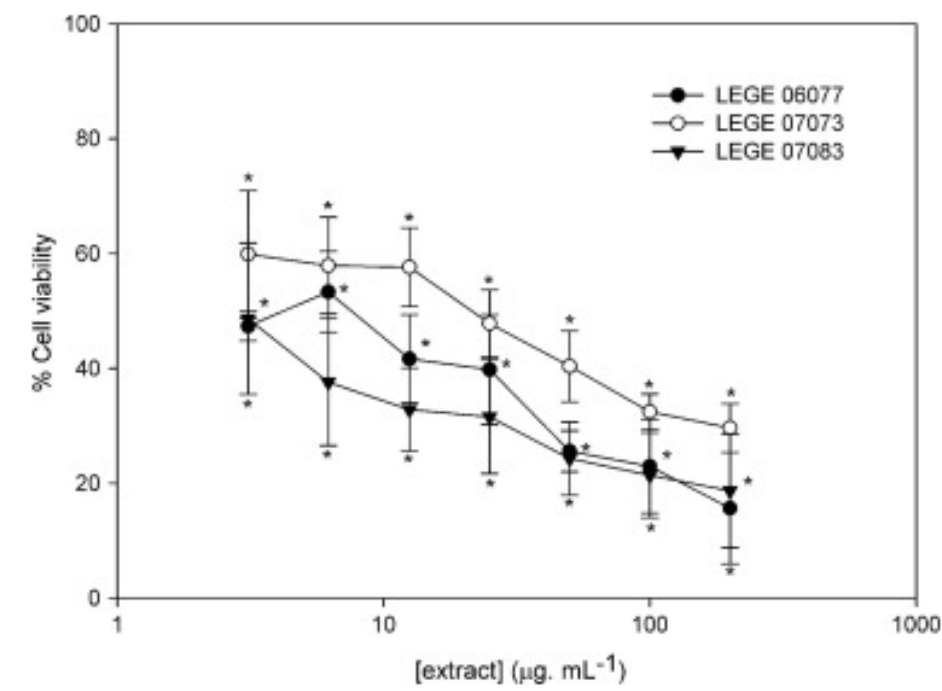

Fig. 1.

CB methanolic crude extracts-induced cytotoxicity profiles after $72 \mathrm{~h}$-exposure time of L929 cell culture using MTT. Cell viability expressed as percentage of control. Results are given as mean and standard deviation of three replicates. The asterisk indicate statistical significance, $p<0.05$. 
The antiviral activity of CB extracts against influenza virus A, HSV-1, CVB3 and HRV-2 was determined by inhibition of viral cytopathic effect (CPE). With the exception of LEGE 07085, influenza virus, CVB3 and HSV-1 showed CPE inhibition less than 20\%, which is considered low antiviral activity. LEGE 07085 showed anti-HSV-1 activity in GMK cells. The concentration required to reduce HSV-1 induced CPE by $50 \%$ was $174.10 \mu \mathrm{g} \mathrm{mL}^{-1}$. No anti-HRV-2 activity was found. The same cell lines used to the antiviral activity assay were also used to evaluate cytotoxicity of the tested extracts. None of the extracts was cytotoxic in HeLa, MDCK, and GMK cells up to the maximum tested concentration of $200.00 \mu \mathrm{gL}^{-1}$ (data not shown).

\section{Discussion}

Cyanobacteria are known to be a rich source of bioactive compounds and for producing toxins harmful to a diversity of organisms such as mammals, fishes, invertebrates and algae. Our data have shown that estuarine cyanobacterial isolates are putative candidates to induce DNA damage on bacteria (E. coli) without metabolic activation. Of a total of 18 crude methanolic $(70 \% \mathrm{v} / \mathrm{v})$ extracts, $5 \%$ had significant genotoxic effects. The genotoxic extract LEGE 06078 belongs to Phormidium genus (Oscillatoriales). In addition, $22 \%$ of the extracts, belonging to the Oscillatoriales and Nostocales families, were considered as potential genotoxic candidates because they have shown IF values higher than 1.5 at higher concentrations values $\left(12.50 \mu \mathrm{g} \mathrm{mL}^{-1}\right)$ but mostly without showing a dose-dependent response. Additionally, the absence of increased levels of alkaline phosphatase suggests that no in vivo cytotoxicity is observed. Nevertheless, decreased activity levels of this enzyme were observed in LEGE 07074 and 06077 extracts in a dosedependent manner, which can affect the galactosidase functioning.

A study of Mankiewicz et al. (2002) had shown genotoxicity (without metabolic activation) by cyanobacterial extracts with the hepatotoxins microcystins. The IF values determined by Mankiewicz et al. (2002) range from 1.1 to 1.7 at $2 \mathrm{mg} \mathrm{mL}^{-1}$ which are slightly lower than the IF values of our data. Moreover, others studies with cyanobacteria, specifically benthic Phormidium strains from Baltic Sea, had shown the presence of apoptosis-inducing substances. Also, Shirahashi et al., 1993 and Teneva et al., 2005 and Surakka et al. (2005) had done a survey with freshwater Phormidium strains and showed that they are potential anti-tumour compounds producers. Nevertheless, the genus Phormidium of benthic estuarine cyanobacteria has far rarely been studied concerning toxin production and its potential effects on human and environmental health. Thus, our data are the first reporting genotoxicity induced by benthic Phormidium of estuarine ecosystems from temperate regions.

The in vitro cytotoxicity tests are based on the concept that toxic chemicals or compounds can affect basic functions of cells which are common among all cells causing measurable cellular functional and structural damage. The choice of cell lines for in vitro cytotoxicity remains difficult as the type of cells available is very diverse (Bubik et al., 2008, Puerto et al., 2009, Surakka et al., 2005 and Takamatsu et al., 2004). Nevertheless, cytotoxicity evaluation with cell cultures allows a rapid, standardized and sensitive way to 
screen a large number of extracts for the presence of biologically harmful molecules. Regarding this, permanent cell lines are easy to maintain in culture and include a homogeneous cell population, being well suited for screening proposes due to the high reproducibility behaviour.

The fibroblast cell line L929 is highly proliferative and is widely used in cytotoxicity testing, mainly regarding toxicity towards cellular viability and proliferation. Fibroblast cells are the most common cells of all types of connective tissues, being actively engaged in the synthesis and upkeep of the collagenous extracellular matrix, also modulating adjacent cell behaviour including migration, proliferation and differentiation. In this way, biological evaluation with fibroblast cell cultures might be regarded as general bioassay, providing reliable information concerning basal cytotoxicity (Freshney, 2000). Among the 54 estuarine cyanobacteria extracts (hexane, methanol and water) tested, only hexane and methanol extracts impaired the viability of L929 fibroblasts. The cytotoxic effects were observed with methanolic and $n$ hexane extracts in a dose- and time-dependent manner, being clear only for exposure times higher than $24 \mathrm{~h}$. The aqueous extracts did not affect the cell viability independently of the dose or exposure-time. The data obtained also point out that methanolic extracts have marked cytotoxic effects, with $\mathrm{CC}_{50}$ values that are slightly lower than those found with the hexane extracts. Members of all the three cyanobacterial orders studied had cytotoxic effects, although the lowest cytotoxic values were observed for Chroococcales and Nostocales. Surakka et al. (2005) had reported high cytotoxicity to human leukemia cells induced by Nostoc, Nodularia, Phormidium and Anabaena benthic strains from littoral habitats of Baltic Sea. Those genera excepting the Phormidium genus belong to the Nostocales family, supporting our findings. Our results showed that none of 18 isolates used in this study produce microcystins, nodularin or saxitoxin. So, we can infer that the observed cytotoxicity may be due to bioactive compounds present in the cyanobacterial extracts not previously described as known cyanotoxins.

The 54 cyanobacterial extracts were also screened for antiviral activity. The aqueous extract, LEGE 07085 , derived from Leptolyngbya isolate showed antiviral activity against HSV1 with an $\mathrm{IC}_{50}$ of $174.10 \mu \mathrm{g} \mathrm{mL}{ }^{-1}$ with low or no toxic effects on GMK cells up to $200 \mu \mathrm{g} \mathrm{mL}^{-1}$. Several reports have been published about antiviral activity on cyanobacteria. The results were found for cyanobacteria from fresh and marine waters belonging mainly to Oscillatoriales and Nostocales orders. The antiviral effects observed were against HSV-1 and 2, influenza A and HIV viruses induced mostly by methanolic extracts \(Hayashi et al., 1996, Hernandez-Corona et al., 2002, Kanekiyo et al., 2007, Kanekiyo et al., 2005, Nowotny et al., 1997, Ohta et al., 1998, Rechter et al., 2006 and Zainuddin et al., 2002). Nevertheless, Hayashi et al. (1996) reported anti-HSV activity $\left(\mathrm{ED}=212 \mu \mathrm{g} \mathrm{mL}^{-1}\right)$ of an aqueous extract of Nostoc in HeLa cell lines. In addition, the previous reports showed that the antiviral compounds and extracts belonged to the polysaccharide, carbohydrates and peptide groups. This might indicate that the compounds present in the cyanobacteria extracts may have highly polar moiety backing up the data now obtained. Furthermore, all the estuarine cyanobacteria extracts showed no long-term cytotoxicity to HeLa Ohio, MDCK and GMK cell lines at concentrations of up to $200 \mathrm{mg} \mathrm{mL}^{-1}$. Thus, the antiviral activity observed is induced by a potential virus-specific compound or mixture that has no effects on cellular metabolism. 
In addition, the MALDI-TOF analysis showed the presence of pheophorbide a and pheophytin a pigments as well as several peaks ranging from 600 to $1400 \mathrm{~m} / \mathrm{z}$ ratio in the crude LEGE 07085 extract. Ohta et al. (1998) reported novel anti-HSV1 substances got from a marine green alga, Dunaliella primolecta, characterized as pheophorbide a like compounds. Thus, we assume that the potential anti-HSV-1 compounds present on the aqueous LEGE 07085 extract may be a pheophorbide like compounds. This work reports that benthic and picoplanktonic estuarine cyanobacteria contain potentially genotoxic, cytotoxic and anti-herpes compounds. It will be important to study those extracts that had positive results with the battery of assays we used, specifically those compounds that inhibited the HSV1.

\section{References}

Abed et al., 2009 R.M.M. Abed, S. Dobretsov, K. Sudesh Applications of cyanobacteria in biotechnology J. Appl. Microbiol., 106 (2009), pp. 1-12

Berridge and Tan, 1993 M.V. Berridge, A.S. Tan Characterization of the cellular reduction of 3(4, 5-dimethylthiazol-2-yl)-2, 5-diphenyltetrazolium bromide (MTT): subcellular localization, substrate dependence, and involvement of mitochondrial electron transport in MTT reduction Arch. Biochem. Biophys., 303 (1993), pp. 474-482

Bubik et al., 2008 A. Bubik, B. Sedmak, M. Novinec, B. Lenarcic, T.T. Lah Cytotoxic and peptidase inhibitory activities of selected non-hepatotoxic cyclic peptides from cyanobacteria Biol. Chem., 389 (2008), pp. 1339-1346

Burja et al., 2001 A.M. Burja, B. Banaigs, E. Abou-Mansour, J. Grant Burgess, P.C. Wright Marine cyanobacteria - a prolific source of natural productsTetrahedron, 57 (2001), pp. 9347-9377

Carmichael, 1994 W.W. Carmichael Toxins of cyanobacteria Sci. Am., 270 (1994), pp. 78-86

Carmichael, 2001 W.W. Carmichael Health effects of toxin-producing cyanobacteria: "The CyanoHABs"Hum. Ecol. Risk Assess., 7 (2001), pp. 1393-1407

Ding et al., 1999 W.-X. Ding, H.-M. Shen, H.-G. Zhu, B.-L. Lee, C.-N. Ong Genotoxicity of microcystic cyanobacteria extract of a water source in China Mutat. Res. Genet. Toxicol. Environ. Mutagen., 442 (1999), pp. 69-77

Freshney, 2000 R.I. Freshney Culture of animal cells: a manual of basic technique (fourth ed.)Wiley-Liss, New York, USA (2000)

Gademann and Portmann, 2008 K. Gademann, C. Portmann Secondary metabolites from cyanobacteria: complex structures and powerful bioactivities Curr. Org. Chem., 12 (2008), pp. 326-341

Hayashi et al., 1996K. Hayashi, J. Hamada, T. Hayashi A screening strategy for selection of antiHSV-1 and anti-HIV extracts from algae Phytother. Res., 10 (1996), pp. 233-237

Hernandez-Corona et al., 2002 A. Hernandez-Corona, I. Nieves, M. Meckes, G. Chamorro, B.L. Barron Antiviral activity of Spirulina maxima against herpes simplex virus type 2 Antiviral Res., 56 (2002), pp. 279-285 
Hirata et al., 2003 K. Hirata, S. Yoshitomi, S. Dwi, O. Iwabe, A. Mahakhant, J. Polchai, K. Miyamoto Bioactivities of nostocine a produced by a freshwater cyanobacterium Nostoc spongiaeforme TISTR 8169 J. Biosci. Bioeng., 95 (2003), pp. 512-517

Jaiswal et al., 2008 P. Jaiswal, P.K. Singh, R. Prasanna Cyanobacterial bioactive molecules - an overview of their toxic properties Can. J. Microbiol., 54 (2008), pp. 701-717

Kanekiyo et al., 2007 K. Kanekiyo, K. Hayashi, H. Takenaka, J.B. Lee, T. Hayashi Anti-herpes simplex virus target of an acidic polysaccharide, nostoflan, from the edible blue-green alga Nostoc flagelliforme Biol. Pharm. Bull., 30 (2007), pp. 1573-1575

Kanekiyo et al., 2005 K. Kanekiyo, J.B. Lee, K. Hayashi, H. Takenaka, Y. Hayakawa, S. Endo, T. Hayashi Isolation of an antiviral polysaccharide, nostoflan, from a terrestrial cyanobacterium, Nostoc flagelliforme J. Nat. Prod., 68 (2005), pp. 1037-1041

Kotai, 1972 J. Kotai Instructions for Preparation of Modified Nutrient Solution Z8 for Algae Norwegian Institute for Water Research, Blindern, Oslo, Norway (1972)

Li and Song, 2007 J. Li, L.R. Song Applicability of the MTT assay for measuring viability of cyanobacteria and algae, specifically for Microcystis aeruginosa (Chroococcales, Cyanobacteria) Phycologia, 46 (2007), pp. 593-599

Lopes et al., 2010 V. Lopes, N. Fernández, R. Martins, V. Vasconcelos Primary screening of the bioactivity of brackishwater cyanobacteria: toxicity of crude extracts to Artemia salina Larvae and Paracentrotus lividus Embryos Mar. Drugs, 8 (2010), pp. 471-482

Makarov et al., 2005 V.A. Makarov, O.B. Riabova, V.G. Granik, P. Wutzler, M. Schmidtke Novel [(biphenyloxy)propyl]isoxazole derivatives for inhibition of human rhinovirus 2 and coxsackievirus B3 replication J. Antimicrob. Chemother., 55 (2005), pp. 483-488

Mankiewicz et al., 2002 J. Mankiewicz, Z. Walter, M. Tarczynska, O. Palyvoda, M. WojtysiakStaniaszczyk, M. Zalewski Genotoxicity of cyanobacterial extracts containing microcystins from Polish water reservoirs as determined by SOS chromotest and comet assay Environ. Toxicol., 17 (2002), pp. 341-350

Martins et al., 2007 R. Martins, N. Fernandez, R. Beiras, V. Vasconcelos Toxicity assessment of crude and partially purified extracts of marine Synechocystis and Synechococcus cyanobacterial strains in marine invertebrates Toxicon, 50 (2007), pp. 791-799

Martins et al., 2008 R. Martins, M. Ramos, L. Herfindal, J. Sousa, K. Skærven, V. Vasconcelos Antimicrobial and cytotoxic assessment of marine cyanobacteria - Synechocystis and Synechococcus Mar. Drugs, 6 (2008), pp. 1-11

Mundt et al., 2001 S. Mundt, S. Kreitlow, A. Nowotny, U. Effmert Biochemical and pharmacological investigations of selected cyanobacteria Int. J. Hyg. Environ. Health, 203 (2001), pp. 327-334

Mundt et al., 1997 S. Mundt, A. Nowotny, R. Mentel, A. Lesnau, U. Lindequist Antiviral activity of the cyanobacterium Microcystis aeruginosa SPH 01 Pharm. Pharmacol. Lett., 7 (1997), pp. 161-163

Nowotny et al., 1997 A. Nowotny, R. Mentel, U. Wegner, S. Mundt, U. Lindequist Antiviral activity of an aqueous extract of the cyanobacterium Microcystis aeruginosa Phytother. Res., 11 (1997), pp. 93-96 
Ohta et al., 1998 S. Ohta, F. Ono, Y. Shiomi, T. Nakao, O. Aozasa, T. Nagate, K. Kitamura, S. Yamaguchi, M. Nishi, H. Miyata Anti-herpes simplex virus substances produced by the marine green alga, Dunaliella primolecta J. Appl. Phycol., 10 (1998), pp. 349-356

Patterson et al., 1993 G.M.L. Patterson, K.K. Baker, C.L. Baldwin, C.M. Bolis, F.R. Caplan, L.K. Larsen, I.A. Levine, R.E. Moore, E. Moore, C.S. Nelson, K.D. Tschappat, G.D. Tuang, M.R. Boyd, J.H.C. II, R.P. Collins, K.R. Gustafson, K.M. Snader, O.S. Weislow, R.A. Lewin Antiviral activity of cultured blue-green (Cyanophyta) J. Phycol., 29 (1993), pp. 125-130

Patterson et al., 1994 G.M.L. Patterson, L.K. Larsen, R.E. Moore Bioactive natural-products from blue-green algae J. Appl. Phycol., 6 (1994), pp. 151-157

Puerto et al., 2009 M. Puerto, S. Pichardo, A. Jos, A.M. Camean Comparison of the toxicity induced by microcystin-RR and microcystin-YR in differentiated and undifferentiated Caco-2 cells Toxicon, 54 (2009), pp. 161-169

Quillardet and Hofnung, 1993 P. Quillardet, M. Hofnung. The SOS chromotest: a review Mutat. Res., 297 (1993), pp. 235-279

Quillardet et al., 1982 P. Quillardet, O. Huisman, R. D’Ari, M. Hofnung SOS Chromotest, a direct assay of induction of an SOS function in Escherichia coli K12 to measure genotoxicity Proc. Natl. Acad. Sci., 79 (1982), pp. 5971-5975

Rechter et al., 2006 S. Rechter, T. König, S. Auerochs, S. Thulke, H. Walter, H. Dörnenburg, C. Walter, M. Marschall Antiviral activity of Arthrospira-derived spirulan-like substances Antiviral Res., 72 (2006), pp. 197-206

Schmidtke et al., 2001 M. Schmidtke, U. Schnittler, B. Jahn, H.M. Dahse, A. Stelzner A rapid assay for evaluation of antiviral activity against coxsackie virus B3, influenza virus $A$, and herpes simplex virus type $1 \mathrm{~J}$. Virol. Methods, 95 (2001), pp. 133-143

Shen et al., 2002 X. Shen, P.K.S. Lam, G.R. Shaw, W. Wickramasinghe Genotoxicity investigation of a cyanobacterial toxin, cylindrospermopsin Toxicon, 40 (2002), pp. 1499-1501

Shirahashi et al., 1993 H. Shirahashi, N. Murakami, M. Watanabe, A. Nagatsu, J. Sakakibara, H. Tokuda, H. Nishino, A. Iwashima Isolation and identification of anti-tumor-promoting principles from the fresh-water cyanobacterium Phormidium tenue Chem. Pharm. Bull. (Tokyo), 41 (1993), pp. 1664-1666

Surakka et al., 2005 A. Surakka, L.M. Sihvonen, J.M. Lehtimaki, M. Wahlsten, P. Vuorela, K. Sivonen Benthic cyanobacteria from the Baltic Sea contain cytotoxic Anabaena, Nodularia, and Nostoc strains and an apoptosis-inducing Phormidium strain Environ. Toxicol., 20 (2005), pp. 285-292

Takamatsu et al., 2004 S. Takamatsu, D.G. Nagle, W.H. Gerwick Secondary metabolites from marine cyanobacteria and algae inhibit LFA-1/ICAM-1 mediated cell adhesion Planta Med., 70 (2004), pp. 127-131

Teneva et al., 2003 I. Teneva, D. Asparuhova, B. Dzhambazov, R. Mladenov, K. Schirmer The freshwater cyanobacterium Lyngbya aerugineo-coerulea produces compounds toxic to mice and to mammalian and fish cells Environ. Toxicol., 18 (2003), pp. 9-20

Teneva et al., 2005 I. Teneva, B. Dzhambazov, L. Koleva, R. Mladenov, K. Schirmer Toxic potential of five freshwater Phormidium species (Cyanoprokaryota) Toxicon, 45 (2005), pp. 711-725 
Wiegand and Pflugmacher, 2005 C. Wiegand, S. Pflugmacher Ecotoxicological effects of selected cyanobacterial secondary metabolites a short review Toxicol. Appl. Pharmacol., 203 (2005), pp. 201-218

Zainuddin et al., 2002 E.N. Zainuddin, S. Mundt, U. Wegner, R. Mentel Cyanobacteria a potential source of antiviral substances against influenza virus Med. Microbiol. Immunol., 191 (2002), pp. 181-182

Zhan et al., 2004 L. Zhan, H. Sakamoto, M. Sakuraba, D.-S. Wu, L.-S. Zhang, T. Suzuki, M. Hayashi, M. Honma Genotoxicity of microcystin-LR in human lymphoblastoid TK6 cells Mutat. Res. Genet. Toxicol. Environ. Mutagen., 557 (2004), pp. 1-6 